\title{
KARAKTERISTIK PADATAN ANAEROBIK HASIL PENGELOLAAN TERINTEGRASI SAMPAH KOTA SEBAGAI PUPUK ORGANIK
}

\section{CHARACTERISTICS OF ANAEROBIC SOLIDS OF RESULTS OF INTEGRATED CITY WASTE MANAGEMENT AS AN ORGANIC FERTILIZER}

\author{
Damsir $^{*}$ dan Ansyori \\ *Program Studi Agroteknologi, Sekolah Tinggi Perkebunan, Lampung \\ Jl. ZA. Pagar Alam No.17A, Raja Basa, Bandar Lampung, Indonesia \\ *)Email: Sier_damsir@yahoo.co.id \\ Makalah: Diterima 1 Mei 2018; Diperbaiki 20 Agustus 2018; Disetujui 27 Agustus 2018
}

\begin{abstract}
The issue of municipal waste is a serious problem that threatens environmental sustainability. One of the efforts to overcome this problem is integrated city waste management in the bioreactor. Integrated management leaves a problem, namely the presence of waste in the form of anaerobic solids. The study aimed to analyze the waste content of anaerobic solids in municipal waste in bioreactors and the potential use as organic fertilizer. The method used in the study was analyzing anaerobic solid waste samples from 5 bioreactors containing various sizes of municipal wastes. Sampling by opening the control hole in the middle part of the bioreactor were A: slury, $B: 1-3 \mathrm{~cm}, C: 4-6 \mathrm{~cm}, D: 7-9 \mathrm{~cm}$, E: without treatment. The sampleswere packed using plastics, then analyzed in laboratory. Observations included analysis of the density of anaerobic solids during the 150-day conversion process in the laboratory. Parameters analyzed included pH, C/N ratio, total solid (TS), volatilesolid (VS), moisture content, nitrite (NO2-N), temperature, and ash content. The results showed that the conversion of anaerobic solids in all sizes of municipal waste in bioreactors showed differences and decreased values indicated by $\mathrm{C} / \mathrm{N}$ ratio, total solid, volatile solid, nitrite (NO2-N), and moisture content, while ash content increasedand temperature of the material fluctuate during the bio-conversion process. All parameters met the standards and were safe to return to the environment as an organic fertilizer.
\end{abstract}

Keywords: anaerobic solids, municipal waste, oganic fertilizer, bioreactor, bio-conversion

\section{ABSTRAK}

Persoalan sampah kota merupakan persoalan serius yang mengancam keberlanjutan lingkungan. Salah satu upaya untuk mengatasi masalah tersebut yaitu pengelolaan sampah kota secara terintegrasi dalam bioreaktor. Namun cara terintegrasi menyisakan persoalan yaitu adanya limbah dalam bentuk padatan anaerobik. Penelitian bertujuan untuk menganalisis kandungan limbah padatan anaerobik sampah kota dalam bioreaktor dan potensi pemanfaatan sebagai pupuk organik. Metode yang digunakan dalam penelitian adalah menganalisis sampel limbah padatan anaerobik dari 5 buah bioreaktor yang berisi berbagai ukuran sampah kota. Pengambilan sampel dengan cara membuka lubang kontrol bagian tengah bioreaktor yaitu A: slury, B: 1-3 cm, C: 4-6 cm, D: 7-9 cm, E: Tanpa pelakuan, selanjutnya sampel di kemas menggunakan plastik kemudian dianalisis di laboratorium. Pengamatan meliputi analisis kadungan padatan anaerobik selama waktu proses bio-konversi 150 hari di laboratorium. Parameter yang dianalisis meliputi pH, C/N Ratio, Total Solid (TS), Volatil Solid (VS), Kadar air, Nitrit $\left(\mathrm{NO}_{2}-\mathrm{N}\right)$, Suhu dan Kadar Abu. Hasil penelitian menunjukkan bahwa konversi padatan anaerobik semua ukuran sampah kota dalam bioreaktor memperlihatkan perbedaan dan terjadi penurunan nilai yang ditampilkan oleh C/N rasio (70,77\% - 20,51\%), Total solid (TS)(34,6\% - 21,9\%), Volatil solid (VS)( 27,8\% - 10,87\%), Nitrit $\left(\mathrm{NO}_{2}-\mathrm{N}\right)(11,92 \mathrm{mg} / \mathrm{L}-0,89 \mathrm{mg} / \mathrm{L})$, kadar air (86,60\%-64,25\%), sedangkan kadar abu terjadi peningkatan nilai $(2,91 \%-7,02 \%)$ dan temperatur bahan berfluktuasi $\left(28^{\circ} \mathrm{C}-31^{\circ} \mathrm{C}\right)$ selama proses bio-konversi. Semua parameter memenuhi standar dan aman untuk dikembalikan ke lingkungan sebagai pupuk organik.

Kata kunci: padatan anaerobik, sampah kota, pupuk organik, bioreaktor, bio-konversi

\section{PENDAHULUAN}

Persoalan sampah merupakan persoalan serius yang mengancam keberlanjutan lingkungan. Polusi yang ditimbulkan oleh timbunan sampah pada tanah, air maupun udara yang merupakan komponen abiotik dalam ekosistem akan berdampak negatif pada kehidupan organisme dalam ekosistem, termasuk manusia sebagai bagian dari ekosistem. Jika organisme dalam ekosistem tidak dapat beradaptasi terhadap kondisi ekosistem yang terpolusi, organisme dapat punah dan kepunahannya tersebut dapat menganggu kestabilan ekosistem. Rusaknya kondisi ekosistem itu pada akhirnya akan mengancam keselamatan organisme lain dalam ekosistem, termasuk keselamatan manusia (Dasgupta, 2012).

Pemerintah menyadari pentingnya pengelolaan dan perlindungan lingkungan hidup sehingga menetapkan UU No. 23 tahun 1997 tentang 
Pengelolaan Lingkungan Hidup dan UU No. 18 Tahun 2008 tentang Pengelolaan Sampah. Sejak Januari 2012 dikampanyekan gerakan Indonesia "Bersih, Asri, Indah (Berseri)" yang mensosialisasikan pengurangan sampah mandiri menggunakan pendekatan 3R (Reduce, Reuse, Recycle). Namun sayangnya gerakan tersebut tidak berjalan baik karena kurangnya sosialisasi pada masyarakat. Hasil penelitian menunjukkan bahwa pembakaran sampah di tempat terbuka akan menghasilkan gas beracun serta dioxin yang berasal dari proses pembakaran plastik dan bahan beracun lain yang ada di dalam sampah. Keberadaan gas beracun tersebut akan menambah polusi udara (Dahuri, 2004). Terkait hal ini UU No. 18 Tahun 2008 tentang pengelolaan sampah membuat larangan bagi setiap orang untuk membakar sampah yang tidak sesuai dengan persyaratan teknis pengelolaan sampah. Namun nampaknya masyarakat belum mendapat sosialisasi yang baik tentang pelarangan tersebut sehingga perilaku membakar sampah di tempat terbuka masih terus dilakukan masyarakat.

Berdasarkan fakta-fakta di atas disimpulkan bahwa permasalahan sampah di Indonesia merupakan permasalahan nasional yang berdampak serius pada kehidupan masyarakat dan kondisi lingkungan sehingga perlu dilakukan upaya-upaya untuk mengoptimalkan implementasi UU No. 18 Tahun 2008 tentang pengelolaan sampah. Untuk itu pemerintah dan masyarakat perlu bekerjasama sesuai peran dan fungsi masing-masing agar dapat mengatasi persoalan sampah, sehingga kita dapat hidup lebih nyaman di lingkungan yang bersih dan sehat.

Saat ini kebutuhan akan pupuk untuk kebutuhan pertanian sangatlah besar dan untuk mengatasi keterbatasan bahan baku pupuk yang selama ini digunakan perlu adanya perolehan pupuk dari bahan lain terutama dari bahan sampah kota.

Pengelolaan sampah organik secara terintegrasi dalam bioreaktor diharapkan dapat menjadi solusi untuk mengatasi permasalahan sampah kota sekaligus mengolah kembali menjadi bahan yang bermanfaat, akan tetapi cara ini masih menyisakan permasalahan. Selain biogas hasil dari proses pengelolaan terintegrasi adalah lindi dan padatan anaerobik. Pengelolaan terintegrasi menghasilkan produksi padatan dalam bentuk padatan anaerobik yang berpotensi untuk dimanfaatkan sebagai pupuk untuk kegiatan pertanian. Kandungan padatan anaerobik yang terdiri dari Nitrit, kalsium, dan bahan organik lainnya sangat bermanfaat dalam perkembangan tanaman. Penelitian bertujuan untuk menganalisis kandungan limbah padatan anaerobik sampah kota dalam bioreaktor dan potensi pemanfaatan sebagai pupuk organik.

\section{BAHAN DAN METODE}

\section{Bahan dan Alat}

Bahan utama dalam penelitian ini adalah padatan anaerobik yang diambil dari hasil pengelolaan terintegrasi berbagai ukuran sampah kota Bandar Lampung dalam bioreaktor dari berbagai ukuran selama proses bio-konversi 150 hari.

Alat yang dipakai adalah Atomic Absorption Spectroscopy (AAS), UV-Vis Spektrofotometer, TOC-Analyzer, High Performance Liquid Chromatography (HPLC), $\mathrm{pH}-$ meter, Mikroskop dengan image processing, peralatan pendukung untuk analisis menggunakan laboratorium Teknologi Manajemen Lingkungan (TML) Institut Pertanian Bogor yang terakreditasi oleh KAN sesuai dengan prosedur APHA (2005).

Metode yang dipakai dalam penelitian adalah menganalisis limbah padatan anaerobik hasil pengelolaan terintegrasi sampah kota dari 5 buah bioreaktor berbagai ukuran yaitu A: slury, B: 1-3 $\mathrm{cm}, \mathrm{C}: 4-6 \mathrm{~cm}, \mathrm{D}: 7-9 \mathrm{~cm}, \mathrm{E}$ : Tanpa pelakuan. Reaktor anaerobik pengelolaan terintegrasi sampah kota ditampilkan pada Gambar 1.

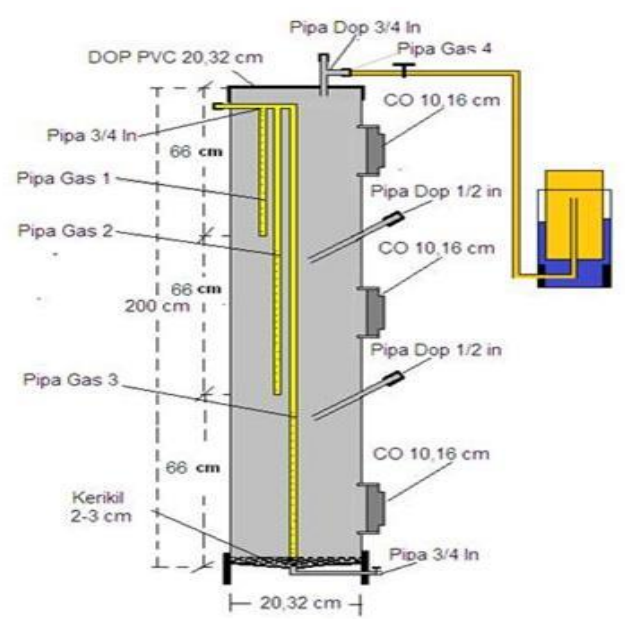

Gambar 1. Reaktor anaerobik pengelolaan terintegrasi sampah kota

Sampel diambil dengan cara membuka lubang kontrol bagian tengah bioraktor. Selanjutnya sampel di kemas menggunakan plastik kemudian dianalisis di laboratorium. Metode analisis yang dipakai dalam penelitian ini seperti yang tertera pada Tabel 1.

Untuk menguji Potensi padatan anaerobik sebagai pupuk organik hasil analisis dibandingkan dengan Permentan No. 70 Tahun 2011 tentang persyaratan pupuk organik. Pengamatan meliputi kualitas padatan anaerobik selama waktu proses biokonversi 150 hari di laboratorium. Parameter yang dianalisis meliputi pH, C/N Ratio, Total Solid (TS), Volatil Solid (VS), Kadar air, Nitrit $\left(\mathrm{NO}_{2}-\mathrm{N}\right)$, Suhu dan Kadar Abu. Selanjutnya data yang diperoleh ditampilkan menggunakan gambar dan grafik. 
Tabel 1. Kualitas padatan anaerobik dan metode analisis yang dipakai

\begin{tabular}{clcl}
\hline No & \multicolumn{1}{c}{ Parameter } & Satuan & \multicolumn{1}{c}{ Metode } \\
\hline 1 & $\mathrm{pH}$ & - & APHA ed. 21th 4500-H ${ }^{+} \mathrm{B}, 2005$ \\
2 & C/N Ratio & - & By Different \\
3 & Total Solid (TS) & $\%$ & APHA ed. 21th 2540 B, 2005 \\
4 & Volatile Solid (VS) & $\%$ & APHA ed. 21th 2540 B, 2005 \\
5 & Kadar Air & $\%$ & SNI 19-7030-2004 \\
6 & Kadar Abu & $\%$ & SNI 19-7030-2004 \\
7 & Nitrit $\left(\mathrm{NO}_{2}-\mathrm{N}\right)$ & $\mathrm{mg} / \mathrm{L}$ & APHA ed. 21th 4500-NO $\mathrm{NO}_{2} \mathrm{~B}, 2005$ \\
8 & Suhu & ${ }^{\circ} \mathrm{C}$ & - \\
\hline
\end{tabular}

\section{HASIL DAN PEMBAHASAN}

\section{Nilai pH}

Pengamatan terhadap padatan anaerobik berbagai ukuran sampah kota pada masing masing perlakuan menunjukkan $\mathrm{pH}$ yang optimal dimulai sejak awal proses sampai akhir proses bio-konversi. Menurut (FFTC, 2005) kondisi proses pengomposan yang optimal berada pada kisaran $\mathrm{pH}$ mendekati netral yaitu $6,8-7,5$. Kondisi $\mathrm{pH}$ yang terlalu tinggi akan berpotensi kehilangan nitrogen akibat penguapan amoniak $\left(\mathrm{NH}_{3}\right)$ dan sebaliknya $\mathrm{pH}$ yang terlalu rendah berdampak pada kematian mikroorganisme (Djuarnani et al., 2005).

Perubahan nilai $\mathrm{pH}$ semua perlakuan selama proses menunjukkan pola yang hampir sama pada awal padatan anaerobik sampai akhir proses (Tabel 2). Hal ini disebabkan oleh perubahan senyawa karbon menjadi asam organik yang mempengaruhi perubahan nilai $\mathrm{pH}$ di dalam proses anaerobik berlangsung sempurna, walaupun tidak tersedianya oksigen yang cukup untuk proses konversi. Penguraian bahan sampah yang banyak mengandung senyawa karbon menjadi senyawa asam organik tidak menghambat nilai $\mathrm{pH}$. Akan tetapi penguraian karbon organik yang lebih kecil juga menghambat proses penguraian pada padatan anaerobik.

Li et al. (2013) melaporkan bahwa asam organik yang terbentuk oleh penguraian karbon organik digunakan kembali oleh mikroorganisme untuk menkonversikan protein menjadi ammonium. Wang et al. (1979) bahwa perubahan $\mathrm{pH}$ selama proses fermentasi disebabkan oleh terbentuknya asam laktat dan asetat. Tosun et al. (2008) Penguraian yang cepat dan sempurna dapat terjadi dalam kondisi yang anaerobik. Secara alami akan terjadi pada saat terjadi peningkatan suhu yang menyebabkan udara hangat keluar dan udara yang lebih dingin masuk ke dalam tumpukan. Kondisi ini mengakibatkan nilai $\mathrm{pH}$ padatan anaerobik sudah memenuhi standar pupuk organik dan tidak memerlukan pengolahan lanjutan. Hal ini terlihat selama proses padatan anaerobik $\mathrm{pH}$ semua perlakuan berada pada kisaran nilai 4,98 - 6,91. sedangkan persyaratan pupuk organik menurut Permentan No.70 Tahun 2011 nilai pH yaitu $4-9$.

\section{Penurunan Kadar Air}

Proses bio-Pengelolaan Terintegrasi berbagai ukuran sampah kota menunjukkan perbedaan laju penurunan kadar air. Komponen sampah yang berukuran lebih besar ternyata memilki kandungan kadar air yang tinggi dibandingkan komponen sampah yang lebih kecil. Adanya pengecilan ukuran pada bahan memberikan pengaruh tehadap laju penurunan kadar air. Hal ini dibuktikan pada bioreaktor A (A: slury) memperlihatkan pola laju penurunan paling rendah. Laju penurunan kadar air yang sangat tinggi ini setelah mengalami proses konversi akan berubah menjadi polutan yang akan mencemari lingkungan berupa lindi. Lindi dapat berfungsi sebagai pembawa penyakit karena di dalamnya sering didapatkan bakteri patogen yang berasal dari sampah (Nurhasanah, 2012).

Kadar air pada semua perlakuan sampai akhir proses konversi sangat tinggi. Hal ini mengindikasikan bahwa kadar air padatan anaerobik belum memenuhi standar untuk dikembalikan ke lingkungan dalam bentuk pupuk organik. Standar kadar air yang ditetapkan Permentan No. 70 Tahun 2011 adalah pada kisaran $13-20 \%$. Oleh karena itu perlu perlakuan lebih lanjut untuk menurunkan kadar air agar padatan anaerobik bisa termanfaatkan sebagai pupuk organik. Penurunan kadar air berbagai ukuran sampah kota ditampilkan pada Tabel 3 .

\section{Suhu Padatan}

Suhu padatan anaerobik berbagai ukuran sampah kota dalam bioreaktor menunjukkan pola yang hampir sama yaitu terjadi penurunan fluktuasi pada minggu pertama selanjutnya stabil sampai akhir proses bio-konversi. Ukuran bahan ternyata memiliki pengaruh terhadap pencapaian suhu yang stabil pada proses awal bio-konversi. Ukuran bahan yang lebih kecil awal proses menujukkan suhu yang tinggi kemudian terus menurun dan stabil setelah minggu pertama. Hal ini dikarenakan proses pematangan pada bahan baku yang lebih kecil akan lebih cepat dibandingkan bahan baku yang lebih besar. Proses penguraian bahan organik dengan adanya peran mikroorganisme yang terdapat pada bahan mempengaruhi kecepatan penguraian. 
Tabel 2. Profil perubahan nilai $\mathrm{pH}$ padatan anaerobik berbagai ukuran sampah kota

\begin{tabular}{ccccccc}
\hline \multirow{2}{*}{$\begin{array}{c}\text { Perlakuan } \\
\text { (ukuran bahan) }\end{array}$} & \multicolumn{6}{c}{ Waktu (hari) } \\
\cline { 2 - 6 } & $\mathbf{0}$ & $\mathbf{3 0}$ & $\mathbf{6 0}$ & $\mathbf{9 0}$ & $\mathbf{1 2 0}$ & $\mathbf{1 5 0}$ \\
\hline A & 4,98 & 4,46 & 4,53 & 5,90 & 6,20 & 6,40 \\
B & 5,61 & 5,44 & 5,66 & 5,59 & 5,40 & 5,80 \\
C & 5,23 & 5,50 & 6,91 & 6,43 & 6,00 & 6,40 \\
D & 5,70 & 5,84 & 5,30 & 5,89 & 5,80 & 5,89 \\
E & 5,26 & 5,19 & 6,32 & 6,20 & 5,70 & 6,21 \\
\hline
\end{tabular}

Keterangan: A: Slury, B: 1-3 cm, C: 4-6 cm, D: 7-9 cm, E: Tanpa perlakuan.

Tabel 3. Penurunan kadar air berbagai ukuran sampah kota selama proses konversi

\begin{tabular}{ccccccc}
\hline \multirow{2}{*}{$\begin{array}{c}\text { Perlakuan } \\
\text { (Bioreaktor) }\end{array}$} & \multicolumn{7}{c}{ Waktu (hari } \\
\cline { 2 - 6 } & $\mathbf{0}$ & $\mathbf{3 0}$ & $\mathbf{6 0}$ & $\mathbf{9 0}$ & $\mathbf{1 2 0}$ & $\mathbf{1 5 0}$ \\
\cline { 2 - 6 } Kadar air (\%) \\
\hline A & 72,47 & 72,10 & 68,90 & 65,67 & 64,96 & 64,25 \\
B & 79,67 & 78,47 & 75,44 & 69,81 & 67,80 & 67,23 \\
C & 80,25 & 79,88 & 79,02 & 72,39 & 67,90 & 67,46 \\
D & 82,91 & 80,65 & 77,12 & 75,40 & 70,20 & 68,98 \\
E & 86,60 & 86,54 & 77,40 & 75,94 & 72,20 & 70,32 \\
\hline
\end{tabular}

Keterangan: A: Slury, B: 1-3 cm, C: 4-6 cm, D: 7-9 cm, E: Tanpa perlakuan

Dengan ukuran bahan yang lebih besar pada prroses padatan anaerobik membuat waktu yang dibutuhkan untuk menguraikan bahan organik akan lebih lama. Aktivitas mikroorganisme berada pada permukaan area yang lebih luas akan meningkatkan kontak antara mikroba dengan bahan dan proses depadatanisi akan berjalan lebih lambat. Hal ini menunjukkan bahwa ukuran partikel juga menentukan besarnya ruang antar bahan (porositas).

Isroi (2008) menyatakan bahwa pada saat sebagian besar bahan telah terurai, maka suhu akan berangsur-angsur mengalami penurunan. Keadaan ini terjadi pematangan padatan tingkat lanjut, yaitu pembentukan komplek liat humus. Selama proses pengomposan akan terjadi penyusutan volume maupun biomassa bahan. Pengurangan ini dapat mencapai $30-40 \%$ dari volume/bobot awal bahan. Li et al. (2013). Pemanfaatan mikroba khususnya bakteri agar optimal biasanya dalam kondisi murni atau spesifik seperti dalam proses fermentasi. Proses penguraian oleh bakteri pada proses fermentasi sangat tergantung dari jumlah dan jenis. Jumlah dan jenis bakteri sangat tergantung dari ketersediaan bahan organik terutama ukuran bahan yang akan dikonversi. Profil perubahan suhu padatan anaerobik diperlihatkan pada Gambar 2.

Perubahan fluktuasi pada semua perlakuan tidak mengalami banyak perbedaan. Fluktuasi ini disebabkan karena pada proses degradasi bahan organik secara anaerobik menghasilkan air yang dapat menurunkan temperatur. Meningkatnya temperatur menandakan bahwa telah terjadi proses konversi bahan organik. Penguraian bahan organik akan menghasilkan gas metan $\left(\mathrm{CH}_{4}\right),\left(\mathrm{CO}_{2}\right),\left(\mathrm{H}_{2} \mathrm{~S}\right)$, $\left(\mathrm{N}_{2} \mathrm{O}\right)$, dan gas lain serta panas. Temperatur merupakan faktor lingkungan yang penting dalam akitivitas mikroorganisme pada proses biologis secara anaerobik. Oleh karena itu hasil pengukuran terhadap temperatur, cenderung mengikuti temperatur lingkungan berkisar antara $29^{\circ} \mathrm{C}$ pagi hari dan $31^{\circ} \mathrm{C}$ siang hari serta $30^{\circ} \mathrm{C}$ sore hari. Kondisi lingkungan termasuk dalam kondisi mesofilik.

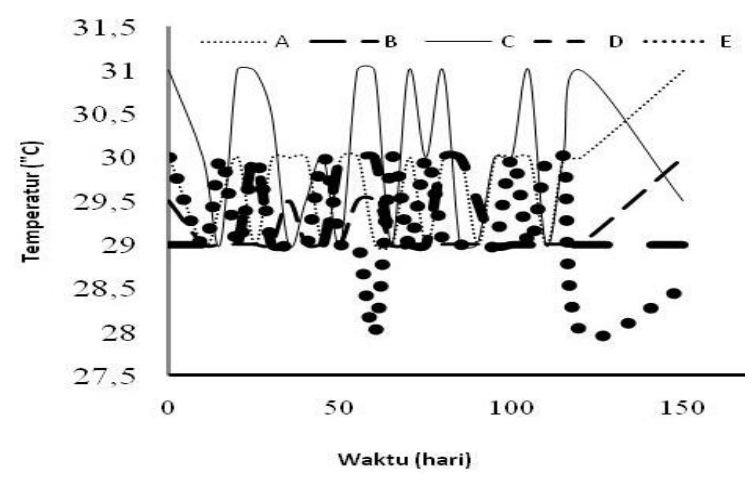

Gambar 2. Profil perubahan suhu pada padatan anaerobik berbagai ukuran sampah kota selama proses konversi. A: slury, B: $1-3 \mathrm{~cm}, \mathrm{C}: 4-6 \mathrm{~cm}, \mathrm{D}: 7-9 \mathrm{~cm}, \mathrm{E}$ : Tanpa pelakuan

Menurut Shearer (2001) temperatur di daerah tropis berkisar $25^{\circ} \mathrm{C}-35^{\circ} \mathrm{C}$ sudah cukup bagus. Chae et al. (2007) menyatakan bahwa pada temperatur $25^{\circ} \mathrm{C}$ gas metan $\left(\mathrm{CH}_{4}\right)$ yang dihasilkan hanya $82,6 \%$ dari produksi pada temperatur $35^{\circ} \mathrm{C}$. Temperatur isian digester berpengaruh terhadap perkembangan bakteri dalam proses Pengelolaan Terintegrasi. Bakteri selulolitik umumnya hidup pada kisaran temperatur optimum $30-35^{\circ} \mathrm{C}$ untuk memproduksi enzim selulosa (Stafford et al., 1980). 


\section{Perubahan Senyawa Nitrit $\left(\mathrm{NO}_{2}-\mathrm{N}\right)$}

Perubahan senyawa nitrit yang terjadi pada proses padatan anaerobik menunjukkan pola yang hampir sama yaitu terjadi kenaikan sampai hari ke 30 dan selanjutnya terjadi penurunan sampai akhir proses. Hal ini terjadi akibat proses nitrifikasi terjadi sampai pada fase 30 hari meningkatkan konsentrasi nitrit dan setelah itu proses nitrifikasi terus menurun. Meuncahng et al. (2005) penurunan konsentrasi nitrit akibat berkurangnya proses nitrifikasi akibat berjalannya waktu yang diakibatkan panas yang tinggi. Oleh karena itu proses pembentukan nitrit pada padatan anaerobik terjadi pada saat suhu tidak terlalu tinggi.

Pada padatan anaerobik bahan A: slury, peningkatan senyawa nitrit paling tinggi dibandingkan bahan yang lain pada 30 hari pertama, pada waktu tersebut terjadi penurunan suhu proses sehingga memungkinkan terjadi nitrifikasi. Hal ini ini menunjukkan bahwa pada padatan anaerobik bahan A faktor suhu terbentuk sebagai akibat proses penguraian bahan organik menjadi salah satu penyebab perubahan senyawa nitrit pada padatan anaerobik yang terbentuk. Perubahan senyawa nitrit berbagai ukuran sampah kota pada proses padatan anaerobik ditampilkan pada Gambar 3.

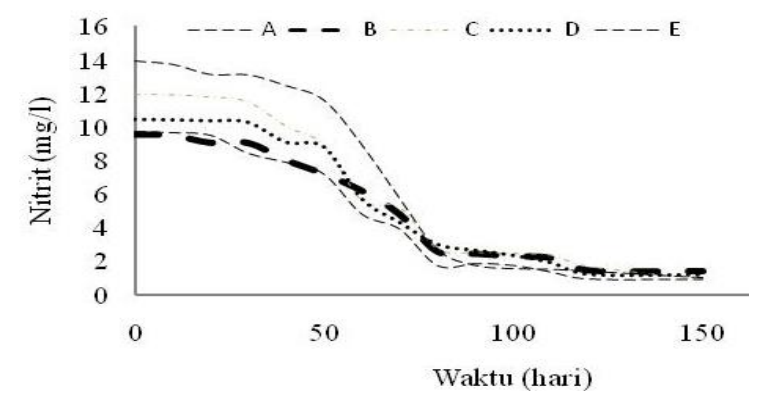

Gambar 3. Perubahan senyawa nitrit berbagai ukuran sampah kota pada proses bio-konvesi anaerobik. A: Slury, B: 1-3 cm, C: 4-6 $\mathrm{cm}, \mathrm{D}: 7-9 \mathrm{~cm}$, E: Tanpa pelakuan

\section{Peningkatan Kadar Abu}

Proses penguraian bahan organik pada proses padatan anaerobik semua perlakuan meningkatkan kadar abu seiring berjalannya waktu. Komponen kadar abu pada bahan A: slury menunjukkan peningkatan tertinggi dibandingkan bahan yang lainnya. Faktor bahan yang mudah terkonversi pada bahan A: slury memudahkan peningkatan kadar abu sampai akhir proses konversi (Gambar 4). Hal ini karena adanya senyawa karbon yang akan menghasilkan panas. Panas yang dihasilkan oleh senyawa karbon mempercepat pelapukan pada bahan. Bahan yang lebih kecil memungkinkan terjadinya proses konversi cepat oleh senyawa karbon daripada bahan yang lebih besar

\section{Penurunan nilai $\mathrm{C} / \mathrm{N}$ Rasio}

Perbandingan penurunan nilai $\mathrm{C} / \mathrm{N}$ menunjukkan perbedaan yang signifikan pada tiga bulan pertama, dimana pada padatan anaerobik bahan ukuran terkecil (A: slury) terjadi penurunan $\mathrm{C} / \mathrm{N}$ yang cukup besar dibandingkan pada ukuran bahan yang lebih besar. Hal ini dimungkinkan adanya penurunan senyawa karbon yang lebih besar pada bahan yang lebih kecil atau meningkatnya senyawa nitrogen. Nilai $\mathrm{C} / \mathrm{N}$ berbagai ukuran sampah kota selama proses konversi ditampilkan pada Gambar 5. Berkurangnya senyawa karbon menjadi $\mathrm{CO}_{2}$ sebagai akibat dari tidak tervolatisasinya senyawa ammonium (Isroi 2008). Tripetchkul et al. (2012) bahwa oksidasi bahan organik pada proses pengomposan menghasilkan karbondioksida, air dan biomassa.

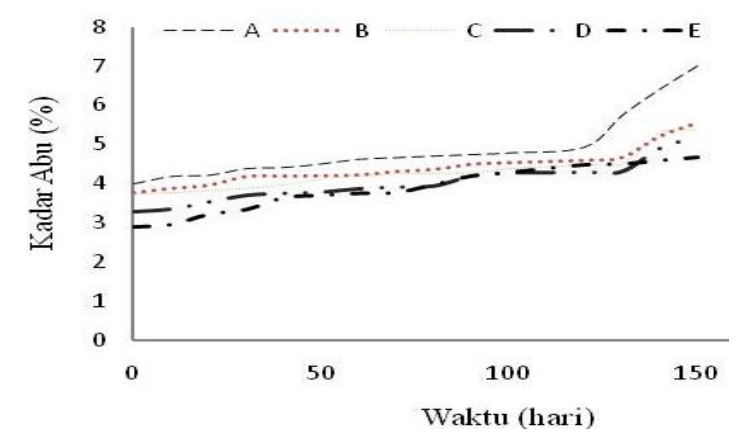

Gambar 4. Peningkatan kadar abu padatan anaerobik berbagai ukuran sampah kota. A: slury, B: $1-3 \mathrm{~cm}, \mathrm{C}: 4-6 \mathrm{~cm}, \mathrm{D}: 7-9 \mathrm{~cm}, \mathrm{E}$ : Tanpa pelakuan

Yaser et al. (2007) melaporkan penurunan senyawa karbon dipengaruhi oleh sumber karbon pada bahan. Semakin mudah untuk diuraikan (biodegredable) maka penurunan bahan organik akan semakin besar. Namun demikian mendekati proses akhir padatan anaerobik, laju penurunan nilai $\mathrm{C} / \mathrm{N}$ semua perlakuan mendekati nilai yang hampir sama. Pada akhir proses padatan anaerobik nilai $\mathrm{C} / \mathrm{N}$ telah sesuai dengan Permentan No. 70 Tahun 2011 untuk pupuk organik sehingga dalam penelitian ini nilai $\mathrm{C} / \mathrm{N}$ aman untuk dikembalikan ke lingkungan sebagai padatan anaerobik. Menurut Permentan No.70 Tahun 2011 syarat nilai C/N pada kisaran $12-25$.

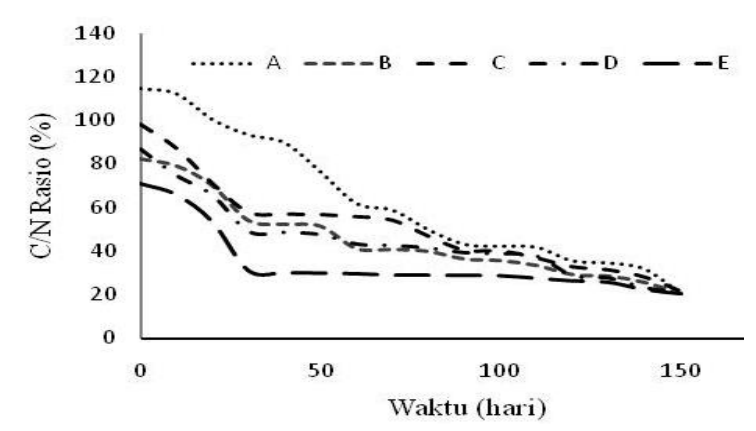

Gambar 5. Nilai $\mathrm{C} / \mathrm{N}$ rasio berbagai ukuran sampah kota selama proses bio-konversi. A: Slury, B: $1-3 \mathrm{~cm}$, C: $4-6 \mathrm{~cm}, \mathrm{D}: 7-9 \mathrm{~cm}$, E: Tanpa pelakuan 


\section{Penurunan Total Solid (TS) dan Volatil Solid (VS)}

Total Solid (TS) selama proses biokonversi pada berbagai perlakuan memperlihatkan kecenderungan menurun (Gambar 6). Begitu juga kondisi Volatil Solid (VS) mempunyai kecenderungan semakin menurun (Gambar 7). Nilai TS pada pada perlakuan A terjadi penurunan nilai paling tinggi. Hal ini terjadi karena bahan organik pada bahan A: slury lebih mudah terkonversi. Keadaan ini disebabkan bahan organik yang telah ada sudah mengalami reaksi hidrolisis hingga reaksi metanogenesis.

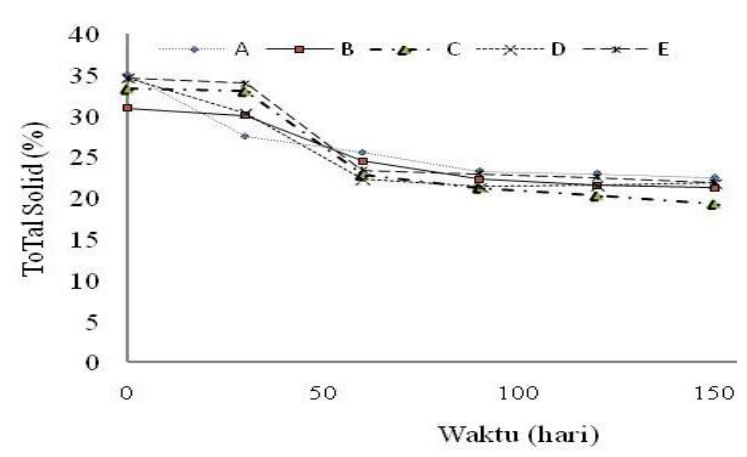

Gambar 6. Nilai total solid (TS) berbagai ukuran sampah kota selama proses biokonversi. A: slury, B: 1-3 cm, C: 4-6 $\mathrm{cm}, \mathrm{D}: 7-9 \mathrm{~cm}$, E: Tanpa pelakuan

Menurunnya kadar TS tersebut merupakan indikator terjadinya bio-konversi secara enzimatis dan aktivitas asidogenesis yang merubah fraksi padatan menjadi fraksi padatan anaerobik. Sebagian padatan yang dapat mengendap sebagai lindi, akan terbawa dalam aliran lindi yang merupakan umpan metanogenesis (Fantozzi dan Buratti, 2011). Penurunan nilai VS paling tinggi yaitu pada perlakuan A. Persentase penurunan kandungan VS dari proses padatan anaerobik pada perlakuan ini menunjukkan bahwa proses tersebut memiliki efisiensi yang lebih baik jika dibandingkan dengan effisiensi perlakuan yang lain. Hal ini dikarenakan ukuran bahan A: slury terjadi percepatan konversi selulosa menjadi glukosa sehingga menjadi bahan yang larut dan mudah dikonsumsi oleh mikroba. Ukuran partikel adalah faktor penting yang mempengaruhi cepat lambatnya proses bio-konversi. Ukuran yang semakin kecil akan memiliki luas permukaan yang lebih besar sehingga akan lebih mudah diuraikan.

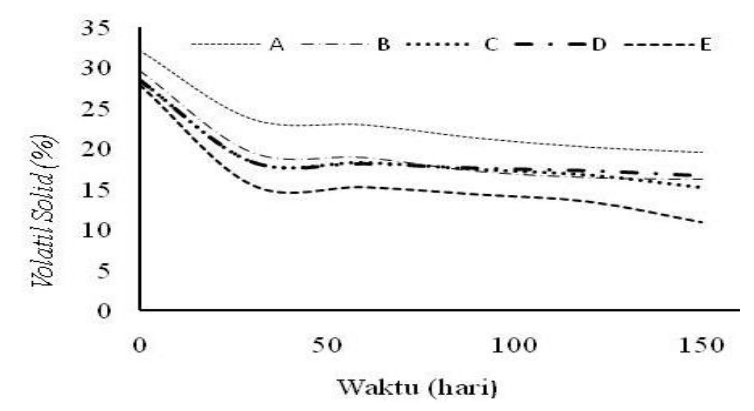

Gambar 7. Nilai volatil solid (VS) berbagai ukuran sampah kota selama proses bio-konvesi anaerobik. A: Slury, B: 1-3 cm, C: 4-6 cm, D: 7-9 cm, E: Tanpa pelakuan

Zhang et al. (2007) bahwa ukuran partikel sampah hendaknya tidak terlalu besar sehingga dapat mempercepat proses konversi. Biodegradabilitas sampah/bahan baku sangat dipengaruhi oleh persentase dari solid (total solid atau volatil solid) yang dihancurkan selama proses pengelolaan terintegrasi dalam jangka waktu tertentu.

\section{Kandungan Padatan Anaerobik}

Hasil analisis kandungan padatan anearobik menunjukkan bahwa semua kadar telah sesuai dengan persyaratan yang ditetapkan dalam Permentan No. 70 Tahun 2011 (Tabel 4). Kandungan Logam berat Cromium $(\mathrm{Cr})$ pada kisaran 0,025-0,035 $\mathrm{mg} / \mathrm{L}$ jauh lebih rendah dibandingkan dengan standar Permentan 2011, sedangkan kandungan logam berat lainnya seperti Cadmium (Cd) pada kisaran 0,003-0,019 mg/L, Timbal $(\mathrm{Pb})$ 0,004-0,011 mg/L, Mercury (Hg) 0,003-0,014 mg/L, Seng (Zn) 0,401-0,621 mg/L, dan Tembaga (Cu) 0,092-0,195 semua berada pada kisaran standar yang dipersyaratkan. Begitu juga dengan kadar Abu pada 4,67- 7,0 \%, NO2-N 0,89-1,42 mg/L, dan C/N Rasio 20,6-21,4\%. Hal ini menunjukkan bahwa padatan anaerobik aman untuk dikembalikan ke lingkungan yang bisa dimanfaatkan dalam bentuk pupuk organik untuk kebutuhan pertanian.

Tabel 4. Hasil analisis akhir kandungan padatan anaerobik

\begin{tabular}{cccccccccc}
\hline \multirow{2}{*}{ Perlakuan } & \multirow{2}{*}{$\mathrm{Abu}(\%)$} & \multirow{2}{*}{$\mathrm{NO}_{2}-\mathrm{N}(\mathrm{mg} / \mathrm{l})$} & \multirow{2}{*}{$\mathrm{C} / \mathrm{N}$ Rasio $(\%)$} & \multicolumn{7}{c}{ Logam Berat $(\mathrm{mg} / \mathrm{l})$} \\
\cline { 5 - 9 } & & & & $\mathrm{Cr}$ & $\mathrm{Cd}$ & $\mathrm{Pb}$ & $\mathrm{Hg}$ & $\mathrm{Zn}$ & $\mathrm{Cu}$ \\
\hline $\mathrm{A}$ & 7,02 & 0,99 & 20,6 & 0,351 & 0,007 & 0,007 & 0,005 & 0,621 & 0,095 \\
$\mathrm{~B}$ & 5,54 & 1,42 & 20,7 & 0,125 & 0,003 & 0,011 & 0,003 & 0,411 & 0,125 \\
$\mathrm{C}$ & 5,36 & 0,95 & 21,4 & 0,019 & 0,005 & 0,009 & 0,006 & 0,401 & 0,195 \\
$\mathrm{D}$ & 5,2 & 1,19 & 21,2 & 0,911 & 0,019 & 0,004 & 0,014 & 0,611 & 0,135 \\
$\mathrm{E}$ & 4,67 & 0,89 & 20,51 & 0,025 & 0,006 & 0,011 & 0,009 & 0,571 & 0,092 \\
Standar & $4,0-10,0$ & $<2$ & $20-25$ & $<210$ & $<2$ & $<50$ & $<1$ & $<5000$ & $<5000$ \\
\hline
\end{tabular}

Keterangan: A: Slury, B: 1-3 cm, C: 4-6 cm, D: 7-9 cm, E: Tanpa perlakuan 


\section{KESIMPULAN DAN SARAN}

\section{Kesimpulan}

Konversi padatan anaerobik semua ukuran sampah kota dalam bioreaktor memperlihatkan perbedaan dan terjadi penurunan nilai yang ditampilkan oleh $\mathrm{C} / \mathrm{N}$ rasio $(70,77 \%-20,51 \%)$, Total solid (TS)( 34,6\% - 21,9\%), Volatil solid (VS) $\left(27,8 \%\right.$ - 10,87\%), Nitrit $\left(\mathrm{NO}_{2}-\mathrm{N}\right)(11,92 \mathrm{mg} / \mathrm{L}$ $0,89 \mathrm{mg} / \mathrm{L})$, kadar air $(86,60 \%-64,25 \%)$, sedangkan kadar abu terjadi peningkatan nilai $(2,91 \%-7,02 \%)$ dan temperatur berfluktuasi $\left(28^{\circ} \mathrm{C}-31^{\circ} \mathrm{C}\right)$ selama proses bio-konversi. Semua parameter memenuhi standar dan aman untuk dikembalikan ke lingkungan sebagai pupuk organik kecuali kadar air yang memerlukan pengolahan lebih lanjut.

\section{Saran}

Pengujian padatan anaerobik terhadap tanaman sebagai pupuk organik diperlukan agar diperolah polutan yang bermanfaat. Pengolahan lebih lanjut untuk menurunkan kadar air padatan anaerobik diperlukan agar kualitas menjadi lebih baik. Untuk menangani persampahan dengan hasil maksimal disarankan para pengambil kebijakan untuk megelola sampah secara terintegrasi.

\section{UCAPAN TERIMA KASIH}

Penulis mengucapkan terima kasih kepada Kementerian Riset Teknologi Dan Pendidikan Tinggi melalui STIBUN Lampung yang telah memberikan bantuan pendanaan melalui Hibah Penelitian Strategis Nasional (STRANAS) Institusi Tahun 2018. Terima kasih juga disampaikan kepada Laboratorium Teknologi Manajemen Lingkungan (TML), Teknologi Industri Pertanian, Institut Pertanian Bogor atas bantuan analisis pengujian sampel dan diskusi.

\section{DAFTAR PUSTAKA}

[APHA] American Public Health Association. 2005. Standart Method for The Examination of Water and Wastewater $21^{\text {th }}$ Edition. Baltimor : Victor Grafihcs Inc. (US).

[FFTC] Food and Fertilizer Technology Center. 2005. Compost Production: A Manual For Asian Farmers. Taipei: Food and Fertilizer Technology Center (FFTC), taipei. (CN).

[IPCC] Intergovernmental Panel on Climate Change. 2001. Summary for Polic ymakers and Technical Summary of Climate Change 2001: Mitigation.Contribution of Working Group III to the Third Assessment Report of the Intergovernmental Panel onClimate Change, di dalam Bert Metz et al. (eds). Cambridge University Press. (US): United Kingdom.
Chae KJ, Jang SK, Yim, IS, Kim. 2007. The effects of digestion temperature and shock on the biogas yields from the mesophilic anaerobikic digestion of swine manure. Journal Bioresource Technology. 99: 1-6.

Dahuri. 2004. Sampah Organik, Kotoran Kerbau Sumber Energi Alternatif, Sumber Media Indonesia.

Dasgupta BV, Mondal MK. 2012. Bio Energy Conversion of Organic Fraction of Varanasi's Municipal Solid Waste. Energy Procedia. 14 : 1931 - 1938.

Djuarnani N, Kristian, Budi SS. 2005. Cara Cepat Membuat Padatan, Jakarta: Agromedia Pustaka.

Drennan MF, Distefano TD. 2010. Characterization of the curing process from high-solid anaerobikic digestion. Journal Bioresource Technology. 101: $537-544$.

Fantozzi F and Buratti C. 2011. Anaerobikic digestion of mechanically treated OFMSW: Experimental data on biogas/methane production and residues characterization. University of Perugia, Biomass Research Centre (CRB), Via G. Duranti, Strada S. Lucia Canetola, 06125 Perugia, Italy. Journal Bioresource Technology.102: 8885-8892.

Isroi. 2008. Padatan. Bogor: Balai Penelitian Perkebunan Indonesia.

Li Y, Li W, Liu B, Wang K, Su C, Wu C. 2013. Ammonia emission and biodegradation of organic carbon during sewage sludge composting with different extra carbon sources. International Biodeterioration \& Biodegradation. 85:624-630.

Meunchang S, Panichsakpatana S, Weaver RW. 2005. Co-Composting of filter cake and baggase, by-product from a sugar mill. Journal Bioresource Technology. 96:437442.

Nurhasanah. 2012. Pengolahan Lindi dan Potensi Pemanfaatannya sebagai Pupuk Cair untuk Mendukung Pengembangan TPA Sampah Lestari. [Disertasi]. Bogor. Institut Pertaanian Bogor.

Peraturan Menteri Lingkungan Hidup. 2014. Baku Mutu Air Limbah. Permen LH 5/ 2014.

Peraturan Menteri Pertanian. 2011. Persyaratan Teknis Minimal Pupuk Organik. Permentan No. 70/Permentan/SR.140/10/2011.

Stafford DA, Hawkes R, Homton. 1980. Methan Production From Waste Organic Matter. CRC Press, Inc. Florida.

Tosun I, Gonullu MT, Arslankaya E, Gunay A. 2008. Co-Composting kinetics of rose processing waste with OFMSW. Journal Bioresource Technology.99:6143-6149.

Tripetchkul S, Pundee K, Koonsrisuk S, Akeprathumchai. 2012. Co-composting of coir pith and cow manure: initial $\mathrm{C} / \mathrm{N}$ ratio vs 
physic- chemical changes. International Journal Recycling Organik Waste in Agriculture. 1:15.

Wang DIC, CL Conney, Demain AM, Dunhill P, Humherry AF, Diely M. 1979. Fermentation and Enzymes Technology. John Willey and Sons.

Wua, Anying Yao, Jun Zhu, and Miller. (2010). Biogas and $\mathrm{CH}_{4}$ productivity by co-digesting swine manure with three crop residues as an external carbon source. Journal Bioresource Technology. 101:4042-4047.

Yadvika, Santosh, Sreekrishnan TR, Kohli S, Rana V. 2004. Enhancement of biogas production from solid substrates using different techniques a review Journal Bioresource Technology. 95: 1-10.
Yaser AZ, Rahman RA, Kalil MS. 2007. Cocomposting of palm oil mill sludge-sawdust. Pakistan Journal of Biological Science. 10(24):4473-4478.

Yuli A, Hidayati, TB. Benito A, Kurnani, Eulis T, Marlina, Ellin Erlia. 2011. Kualitas pupuk cair hasil pengolahan feses sapi potong menggunakan Saccharomyces cereviceae. Jurnal Ilmu Ternak. 11(2): 104-107.

Zhang R, El-Mashad HM, Hartman K, Wang F, Liu G, Choate C, Gamble P. 2007. Characterization of food waste as feedstock for anaerobikic digestion Journal Bioresource Technology. 98 : 929 - 935. 